\title{
Psychrotolerance Mechanisms in Cold-Adapted Bacteria and their Perspectives as Plant Growth-Promoting Bacteria in Temperate Agriculture
}

\author{
Parthiban Subramanian, Manoharan Melvin Joe, Woojong Yim, Bohui Hong, Shertyn C. Tipayno, \\ Venkatakrishnan Sivaraj Saravanan ${ }^{1}$, Jaehong $\mathrm{Yoo}^{2}$, Jongbae Chung ${ }^{3}$, Tahera Sultana ${ }^{4}$, and Tongmin Sa* \\ Department of Agricultural Chemistry, Chungbuk National University, Cheongju, Chungbuk 361-763, \\ Republic of Korea, ${ }^{I}$ Department of Microbiology, Indira Gandhi College of Arts and Science, \\ Pondicherry 605009, India, ${ }^{2}$ Department of Agricultural Biology, Agricultural Microbiology Division, \\ RDA, Suwon 441-707, Republic of Korea, ${ }^{3}$ Division of Life and Environmental Science, Daegu University, \\ Gyeongsan, Kyungbuk, 712-714, Republic of Korea, ${ }^{4}$ Department of Biology and Oceanography, \\ Inha University, Incheon, Republic of Korea
}

\begin{abstract}
Cold-adapted bacteria survive in extremely cold temperature conditions and exhibit various mechanisms of adaptation to sustain their regular metabolic functions. These adaptations include several physiological and metabolic changes that assist growth in a myriad of ways. Successfully sensing of the drop in temperature in these bacteria is followed by responses which include changes in the outer cell membrane to changes in the central nucleoid of the cell. Their survival is facilitated through many ways such as synthesis of cryoprotectants, cold acclimation proteins, cold shock proteins, RNA degradosomes, Antifreeze proteins and ice nucleators. Agricultural productivity in cereals and legumes under low temperature is influenced by several cold adopted bacteria including Pseudomonas, Acinetobacter, Burkholderia, Exiguobacterium, Pantoea, Rahnella, Rhodococcus and Serratia. They use plant growth promotion mechanisms including production of IAA, HCN, and ACC deaminase, phosphate solublization and biocontrol against plant pathogens such as Alternaria, Fusarium, Sclerotium, Rhizoctonia and Pythium.
\end{abstract}

Key words: Psychrotrophs, Psychrophiles, Cold-adaptation Mechanisms, Plant growth-promoting bacteria

\section{Introduction}

About more than $80 \%$ of the earth's surface is exposed to temperature of $15^{\circ} \mathrm{C}$ or below at various times of the year (Kawahara, 2002). In particular, soils that belong to the temperate regions are subjected to seasonal drop in temperature for a considerable portion of a year, during which, any biological activity is low or even negligible due to intermittent dropping of soil temperatures to suboptimal ranges (Robertson and Grandy, 2005). This has led to short cropping periods for agriculture in the temperate regions (Mishra et al., 2011a). Cold stress causes a major metabolic response in plants, affecting their growing periods and consequently resulting in loss of agricultural production (Chu et al., 2010). The effect and

\footnotetext{
Received : July 15. 2011 Accepted : August 17. 2011

*Corresponding author : Phone: +82432612561

E-mail: tomsa@chungbuk.ac.kr
}

importance of cold stress, along with other abiotic stresses on agricultural productivity was discussed by Boyer (1982). The significance of low temperature as one of the major agricultural barriers exists till date even decades after Boyer's report. Evidence to support this can be taken from northern temperate countries such as Sweden or Canada, where a combination of cold stress and high light were found to be major problem affecting the agricultural economy (Mittler, 2006). Improving plants by introducing traits such as frost hardiness through breeding or genetic transformations is not completely feasible (Kasuga et al., 1999) as the property of cold resistance cannot be caused through expressing a single gene, but includes complex mechanisms acting together to protect the plant against cold (Beck et al., 2004; Fowler and Thomashow, 2002).

Bacteria thriving under cold conditions are found in abundance over the earth's surface, including the Polar Regions, temperate regions and deep sea depths. With 
respect to agriculture, about $20 \%$ of organic matter in arable soils is the living biomass consisting mainly of soilborne microorganisms and insect decomposers. Sustenance of soil health is predominantly dependent on these soil organisms (Robertson and Grandy, 2005). Therefore, as an integrated measure towards management of cold stress, bacteria may play an inevitable role and help in promoting plant growth under short time periods. This review focuses on the definition of psychrophiles and psychrotrophic bacteria, their cold sensing mechanisms and adaptations and finally, their applications in agriculture, in particular, their role in the cereal and legume crop production.

\section{Definition of Psychrophiles and}

\section{Psychrotrophs}

The terms psychrophiles and psychrotrophs are often found to be confused in usage. The term Psychrophiles was defined by Morita back in 1975 to be microorganisms that have an optimum temperature of growth around $15^{\circ} \mathrm{C}$ or less (Moyer and Morita 2007). Psychrophilic bacteria include Gram-negative genera such as Pseudoalteromonas, Moraxella, Psychrobacter, Flavobacterium Polaromonas, Psychroflexus, Polaribacter, Moritella, Vibrio and Pseudomonas; Gram-positive Arthrobacter, Bacillus and Micrococcus species and several psychrophilic species of archaea, yeasts, fungi and microalgae (Feller and Gerday, 2003).

Psychrotrophs, on the other hand, refer to bacteria that can only survive low temperatures but have optimal temperature of growth above $15^{\circ} \mathrm{C}$ (Moyer and Morita, 2007). Various psychrotrophs have been reported from several bacterial genera included Pseudomonas, Brochothrix, Buttiauxella, Carnobacterium, Halomonas, Leuconostoc, Acinetobacter, Exiguobacterium, Serratia, Rhodococcus, Rahnella, Pantoea (Ercolini et al., 2009; Pandey et al., 2006; Mishra et al., 2008; Gulati et al., 2009; Selvakumar et al., 2010, 2008a, 2008b; Trivedi et al., 2007; Egamberdiyeva and Höflich, 2003; Vyas et al., 2010).

Gow and Mills in 1984 tried to differentiate psychrophiles from psychrotrophs by calculating the number of bacterial colonies in agar plates incubated at temperature conditions optimal for both classes of bacteria. It was observed that psychrotrophic bacteria were capable of exhibiting growth over a wide temperature range and they could even grow at around freezing temperature conditions (Hébraud and Potier, 1999). Therefore, psychrotrophs are considered more versatile than psychrophiles as they are ubiquitous in most of the environments including permanently frozen Polar Regions (Ray, 2006).

\section{Cold Temperature Sensing and Responses in Bacteria}

Primary sensing of drop in environmental temperature in bacteria occurs at the cellular membrane through active phosphorylation and dephosphorylation mechanisms (Ray et al., 1994a; Shivaji and Prakash, 2010). The general signal transduction pathway to perceive cold signal in bacteria has been proposed to be a two component system (Shivaji and Prakash, 2010). This process is explained in Fig. 1. The first component is the sensor embedded in the cell membrane which encloses a sensory domain and the enzyme histidine kinase. The sensory domain is transmembrane in nature and found to contain numerous interspersed segments. Drop in temperature is perceived through these segments and autophosphorylation of the histidine by histidine kinase takes place. The phosphate is then transferred to aspartate component of the response regulator present in the cytoplasm, which contains a DNA binding domain and a transcription activation domain

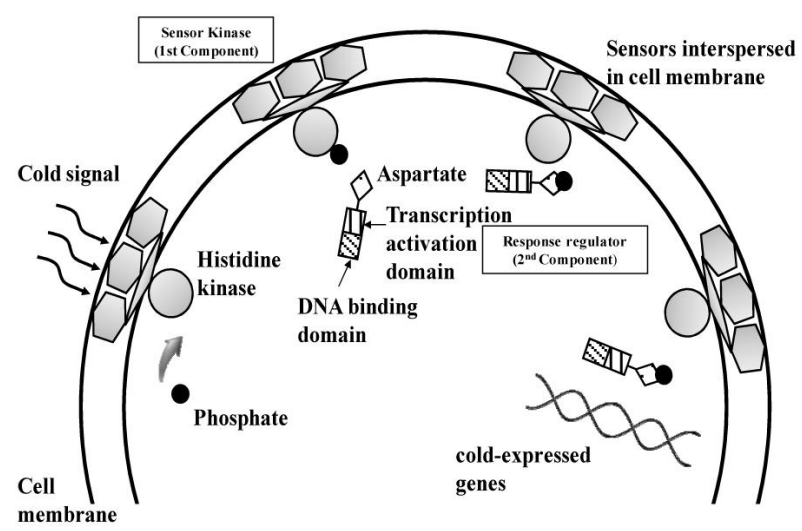

Fig. 1. A simple two-component system of signal transduction under cold condition is represented here. The first component (sensor) is embedded in the cell membrane which encloses a sensory domain and histidine kinase. As seen in the figure, the sensory domain is transmembrane in nature. Cold sensing initiates autophosphorylation of the histidine by histidine kinase. The phosphate group is then transferred to the second component (response regulator), present in the cytoplasm and thus its aspartate is phosphorylated. In addition, response regulator contains a DNA binding domain and a transcription activation domain. Consequently, the response regulator initiates the transcription of various cold expressed genes such as des genes, $\operatorname{csp} A, a f p A$, etc. 
(Shivaji, 2007). A similar $66 \mathrm{kDa}$ cytosolic protein which was found to be phosphorylated at its tyrosine residue, was reported much earlier and may also function as a response regulator (Jagtap and Ray, 1999). The response regulator in addition acts as a transcriptional regulator and performs the function of transcription initiation of various cold expressed genes. This pathway is comparatively simple and can also occur in complex form involving a phosphate cascade or relay systems in some cells (Appleby et al., 1996; Zhang and Shi, 2005).

Exposure to lower temperatures resulted in the nucleoid of bacteria becoming compact (Weber et al., 2001), which might have occurred due to temperature drop or alterations in the activity and/or quantities of proteins responsible for maintaining DNA structure (Jones et al., 1992). Low temperature sensing has been also observed through changes in the secondary or tertiary structures in ribosome (Ray et al., 1998) and mRNAs (Liu et al., 2002). Cold shock is also found to affect translation, which in turn arrests or reduces the growth in bacteria (Shivaji and Prakash, 2010).

\section{Various Modes of Adaptation of Bacteria to Low Temperatures}

Bacteria need to survive and continue life has led to various adaptations in response to cold conditions. These include structural and physiological modifications in the cell to counteract reduction in the reaction rates due to the drop in temperature (D'Amico et al., 2002). Some of the mechanisms of adaptation by bacteria to cold temperature are discussed here. A concise report on various adaptation mechanisms has been provided in Table 1 .

Changes associated with the cell membrane The changes that have been reported in the membrane with respect to low temperature are as follows: changes in membrane lipids, changes in size, length, branching, cis-trans configurations and desaturation of membrane lipids. Changes in fatty acids were found to affect the interaction of proteins on the membrane lipids as well the composition of carotenoids (Kiran et al., 2004; Shivaji and Prakash, 2010; Chattopadhyay, 2006; Russell, 1997; Hébraud and Potier, 1999). Desaturation of the membrane lipids with the help of desaturases was one of the common mechanisms to survive under cold stress (Mishra et al., 2011a). In addition to desaturation, other effective adaptations in the membranes include changes in fatty acid isomerization and increased carotenoid synthesis in the membrane (Shivaji and Prakash, 2010). In some Bacillus sp., increase in anteiso-branched fatty acids was found to increase membrane fluidity at low temperatures compared to iso

Table 1. General cold adaptation mechanisms in bacteria.

\begin{tabular}{|c|c|c|c|}
\hline Vicinity & Nature of adaptation & Protective function & References \\
\hline Cell outer space & Ice nucleator proteins & $\begin{array}{l}\text { Imitate ice crystal surface outside } \\
\text { cell membrane and inhibit supercooling }\end{array}$ & Kawahara, 2002 \\
\hline \multirow[t]{3}{*}{ Cell membrane } & $\begin{array}{l}\text { Unsaturation of } \\
\text { membrane lipids }\end{array}$ & Improves membrane fluidity & Russel, 1997 \\
\hline & $\begin{array}{l}\text { Conversion of trans- } \\
\text { unsaturated fatty } \\
\text { acids to cis- } \\
\text { unsaturated fatty acids }\end{array}$ & Increase membrane fluidity & Kiran et al., 2005 \\
\hline & $\begin{array}{l}\text { Increase in number } \\
\text { of polar carotenoids }\end{array}$ & Stabilizes cell membrane & $\begin{array}{l}\text { Chattopadhyay and } \\
\text { Jagannadham, } 2001\end{array}$ \\
\hline \multirow[t]{6}{*}{ Cytoplasm } & $\begin{array}{l}\text { Enzymes forming } \\
\text { tetramers }\end{array}$ & Increases thermostability of enzymes & Coker et al., 2003 \\
\hline & Cryoprotectants & $\begin{array}{l}\text { Stabilize cell membrane (glycine betaine), } \\
\text { nitrogen reserves (polyhydroxyalkonate) }\end{array}$ & $\begin{array}{l}\text { Chattopadhyay, 2002; } \\
\text { Methe et al., } 2005\end{array}$ \\
\hline & $\begin{array}{l}\text { Cold acclimation } \\
\text { proteins }\end{array}$ & Chaperones to refold denatured enzymes & Kawahara et al., 2000 \\
\hline & Cold shock proteins & $\begin{array}{l}m \text {-RNA chaperone and maintenance of } \\
\text { DNA structure and other metabolic functions }\end{array}$ & $\begin{array}{l}\text { Chattopadhyay, 2006; } \\
\text { Russel, } 1997\end{array}$ \\
\hline & RNA degradosomes & Reduce ATP consumption by RNA helicase & Purusharath et al., 2005 \\
\hline & Antifreeze proteins & $\begin{array}{l}\text { Modify ice crystals and inhibit re- } \\
\text { crystallization of ice }\end{array}$ & Xu et al., 1998 \\
\hline
\end{tabular}


forms (Kaneda, 1991; Okuyama et al., 1991). Increase in levels of $c i s$-unsaturated fatty acids was favored at lower temperatures as $c i s$-unsaturated fatty acids increase fluidity of the membrane compared to trans-unsaturated fatty acids (Heipieper et al., 2003; Shivaji and Prakash, 2010).

In general, carotenoid pigments were found to be synthesized as a result of various environmental stresses; their functional role can be associated to shifts in membrane permeability under cold conditions (Chattopadhyay, 2006). Increase in polar carotenoids and a consequent decrease in non-polar carotenoids have been reported at low temperatures (Jagannadham et al., 2000; Chattopadhyay and Jagannadham, 2001). These carotenoids were found to be stacked in the cellular membranes and their arrangement provides stabilization to the cell membrane effecting permeability (Gruszecki and Strzałka, 2005; Jagannadham et al., 1996, 2000).

Changes in enzymes Drop in the environmental temperature conditions from $37^{\circ} \mathrm{C}$ to $0^{\circ} \mathrm{C}$ was found to affect mesophilic enzymes by inhibiting their activity by 20-250-times (Feller and Gerday, 2003). Maintaining stability by increasing the rigidity of protein structure will reduce the activity of the enzyme. Therefore, the enzyme needs to be flexible which will favor reduced energy expense (Chattopadhyay, 2006). Consequently, the enzyme must exhibit a balance between flexibility and stability to sustain freezing temperatures (D'Amico et al., 2002); the property of being flexible, offering a logical reason for high specificity of cold active enzymes (Huston et al., 2004). The explanation put forth by D'Amico and coworkers (2002) for structural adaptations of cold-adapted enzymes include decrease in number of proline and arginine residues and increase and clustering of glycine. This explanation however, was found to be in conflict with Coker's (2003) comparison of psychrophilic and mesophilic enzyme constituents ( $\beta$-galactosidase) obtained from Arthrobacter. He suggested that the thermo stability of the enzyme maybe due to formation of tetrameric structures, which disassociated into inactive monomers at $25^{\circ} \mathrm{C}$ (Coker et al., 2003). Report from Gianese and coworkers (2001) supported Coker's argument when it claimed that the substitutions of amino acids such as glutamine, valine, arginine, and lysine present in mesophilic or thermophilic enzymes by alanine, serine, aspargine and isoleucine in cold-active enzymes influence the enzyme structure. In conclusion, maintaining a balance in activity- stability-flexibility relationship to actively maintain their function under freezing conditions is a widely accepted hypothesis (Johns and Somero, 2004).

Cryoprotectants Cryoprotectants are defined as substances that accumulate in body fluids of higher living forms, such as frogs and insects (Chattopadhyay, 2006). They are also referred as compatible solutes and include generally sugars, sugar alcohols and sometimes amino acids. Trehalose, glycine betaine and carnitine are commonly found cryoprotectants, while glycerol, sorbitol, manitol, glucose, fructose, alanine and proline were also found to have similar functions in bacteria (Shivaji and Prakash, 2010; Mishra et al., 2011a; Chattopadhyay, 2006). The term cryoprotectants also extended to molecules accumulated in bacteria adapted to cold environmental conditions. Their function was to protect cells by acting as chemical chaperones, preventing processes of protein denaturation and aggregation (Shivaji and Prakash, 2010). Among the compatible solutes in bacteria, the role of glycine betaine maybe possibly attributed to maintaining the fluidity of cell membrane (Chattopadhyay, 2002). Trehalose was found to function in stabilizing cell membranes and proteins by replacing water, thereby, preserving intracellular water structure (Sano et al., 1999). In Colwellia psychrerythraea, accumulation of cryoprotectant polymers like polyhydroxyalkanoate has been reported, with its production seemingly enhanced at -8 to $-14^{\circ} \mathrm{C}$ (Methe et al., 2005; Marx et al., 2009).

Cold acclimation proteins Shortly called "Caps", the cold acclimation proteins are produced in bacteria that grow in permanently cold environments (Hébraud and Potier, 1999; Mishra et al., 2011a). These proteins have been reported by a number of workers (Araki, 1992; Roberts and Inniss, 1992; Piette et al., 2011). Due to their presence in bacteria growing at permanently cold environments, these proteins can serve as markers in distinguishing psychrotrophs from mesophiles (Hébraud and Potier, 1999). Cold acclimation proteins are believed to be responsible for sustenance of life as they are found to facilitate synthesis of adequate amounts of cellular proteins even under cold stress (Margesin et al., 2007). A cold acclimation protein (Hsc 25) isolated from Pantoea ananas KUIN-3 was envisaged to function in the refolding of cold denatured enzymes (Kawahara et al., 2000). 
Cold shock proteins Cold shock is described as the action of shifting the environmental temperature of bacteria from mesophilic conditions to a much lower temperature within a short duration of time (Hébraud and Potier, 1999; Mishra et al., 2011a). Such an event is implausible in natural environments, however, they are created in laboratories to study the mechanisms involved in cold shock response (Hébraud and Potier, 1999). Bacteria were found to respond to cold shock by transiently synthesizing cold shock proteins (Csps) which were found to be present in both mesophilic and psychrophilic bacteria (Chattopadhyay, 2006). Cold shock response included induction of Csp genes, which in turn will regulate synthesis of cellular proteins and mRNA (Mishra et al., 2011a; Polissi et al., 2003). Cold shock proteins were found to contain the DNA binding domain called the cold-shock domain, regarded as one of the most conserved domains through evolution of life (Graumann and Marahiel, 1999).

Cold shock proteins accounted for a large fraction of proteins synthesized during cold shock events (Goldstein et al., 1990). In Escherichia coli, the Csps identified include histone-like proteins, RNA-binding proteins, transcription factors, acyl lipid desaturases, subunit of DNA gyrase, heat shock protein (Hsc 66) and $\gamma$-glutamyl-transpeptidase (Chattopadhyay, 2006). A DNA-binding protein, H-NS associated with the nucleoid was induced during cold shock and protects the E. coli against cold shock in addition to improving its growth (Russell 1997). Cold shock protein A (Csp A), the most common protein expressed during cold shock is found to act as a mRNA chaperone and is involved in transcriptional regulation of various other cold shock genes (Mishra et al., 2011a; Chattopadhyay, 2006). Homologues of Csp A gene was also reported from Arthrobacter protophormiae and Pseudomonas fluorescens, the psychrophilic bacteria isolated from the Antarctic regions, suggesting its role as cold acclimation protein as well (Ray et al., 1994b). Though expression of Csps and homologues of such proteins is intricate, they can be controlled in bacteria at transcription and translational level (Horn et al., 2007).

RNA degradasomes Degradosomes are complexes made of proteins present in most bacterial cells and are involved in maintaining the stability of cellular RNA molecules (Chattopadhyay, 2006). In E. coli, the RNA degradosome was found to be comprised of an endoribonuclease RNAse E, a RNA helicase and an exoribonuclease (polynucleotide phosphorylase) (Carpousis, 2002). However, in Pseudomonas syringae isolated from Antarctic region, the exoribonuclease component was replaced with RNAse $\mathrm{R}$ that performs similar function. It is believed that RNAse $\mathrm{R}$ can degrade RNAs due to their extensive secondary structures, consequently reduce the need of ATP by RNA helicase to unwind RNA duplexes, thereby saving energy at low temperatures (Purusharth et al., 2005).

Antifreeze proteins Antifreeze proteins (AFPs) are a large group of molecules that influence the structures of extracellular ice crystals (Raymond and DeVries, 1977). These proteins prevent recrystallization of ice crystals, which are detrimental to the cell during supercooling at freezing temperatures (Knight et al., 1988; Chattopadhyay, 2006). This process referred as thermal hysteresis, was demonstrated in Psychrobacter urativorans and Rhodococus erythropolis (Duman and Olsen, 1993). Antifreeze proteins have been reported from a number of bacteria, with first reports by Yamashita and co-workers (2002) in the bacterium Moraxella sp. Following this, AFPs were reported in bacteria from Antarctic lakes including Pseudomonas putida and Marinomonas primoryensis (Gilbert et al., 2004; Muryoi et al., 2004; Gilbert et al., 2005).

Ice nucleator proteins Ice nucleator proteins (INPs) are molecules present on the outer cell membrane of bacteria and inhibit heterogeneous ice-nucleation processes common in cold environments, by imitating ice crystal structure surface (Kawahara, 2002). By mimicking the freezing effect on the outer surface of the cell, these molecules help to prevent harmful intracellular freezing in bacteria (Zacharuassen and Kristiansen, 2000). Ice nucleating proteins were found to contain an octapeptide chain repeated contiguously and their structure elicitation showed presence of three distinct domains (Kawahara, 2002). Three classes of INPs were reported, which are structurally similar to lipoglycoproteins, glycoproteins and proteins (Turner et al., 1991). Their expression depends on the external crystal lattice, surface charge and degree of hydrophobicity (Franks, 1985). Bacteria that possessed ice nucleation active (Ina) protein on the outer cell wall, that acts as nucleating centers were called as "ice plus" bacteria (Lee et al., 1995). Those bacteria which lacked these proteins on their outer walls were called "ice minus" bacteria and were deficient in ice nucleating function (Mishra et al., 2011a). INPs have been reported in various species of Pseudomonas, Pantoea, 
Xanthomonas, and some fungi (Maki et al., 1974; Lindow et al., 1978; Kozloff et al., 1983; Obata et al., 1990; Kawahara, 2002).

Other mechanisms In addition to the above mentioned mechanisms of adaptations to cold temperatures, numerous other reports suggested other mechanisms, such as increase in rates of transcription and translation of several metabolically important molecules, acceleration of metabolic pathways, such as the pentose phosphate pathway and entering into viable but nonculturable states (Liu et al., 2002; Sardesai and Babu, 2001, Chattopadhyay, 2000).

\section{Use of Cold Adapted Microorganisms in Agriculture}

A lot of work has been made on cold adapted plant growth promoting psychrotrophs in the past decade which are mentioned briefly in Table 2. Most of such studies, on application of psychrotrophic bacteria in agriculture have been reported from India, concentrated along the Himalayan region (Mishra et al., 2009, 2008, 2010; Vyas et al., 2010; Selvakumar et al., 2008a, 2008b, 2010, 2011; Pandey et al., 2006; Gulati et al., 2009). As low temperature acts a major factor affecting distribution and growth of many plant species, growth and productivity of economically important crops, like rice, wheat and soybean cultivated in the temperate regions were found to be affected by cold (Guy, 1990; Solanke and Sharma, 2008). Cold-adapted microorganisms can be supportive to these plants by mitigating the detrimental effects of cold and help improve productivity even under unfavorable temperature conditions.

\section{Cold-Adapted Plant Growth Promoting Rhizobacteria in Cereal Crops and Legumes}

Psychrotolerant bacteria have been reported to possess plant growth promoting traits and their association with

Table 2. Psychrotrophic bacteria from various environments in the past decade and observed plant growth promoting traits.

\begin{tabular}{|c|c|c|c|}
\hline Organism & Environment & PGP traits & Reference \\
\hline Mycobacteruim phlei MbP18 & $\begin{array}{l}\text { Root zone soil of } \\
\text { winter wheat }\end{array}$ & $\begin{array}{l}\text { Improved growth of } \\
\text { winter wheat in nutrient } \\
\text { poor calcisol soil }\end{array}$ & $\begin{array}{l}\text { Egamberdiyeva and } \\
\text { Höflich (2003) }\end{array}$ \\
\hline Mycoplana bullata MpB46 & $\begin{array}{l}\text { Root zone soil of } \\
\text { maize }\end{array}$ & $\begin{array}{l}\text { Improved growth of } \\
\text { winter wheat in nutrient } \\
\text { poor calcisol soil }\end{array}$ & $\begin{array}{l}\text { Egamberdiyeva and } \\
\text { Höflich (2003) }\end{array}$ \\
\hline Pseudomonas putida (B0) & $\begin{array}{l}\text { Soil from Central } \\
\text { Himalayas }\end{array}$ & $\begin{array}{l}\text { P- Solublization, biocontrol to } \\
\text { Alternaria alternata, } \\
\text { Fusarium oxysporum }\end{array}$ & Pandey et al. (2006) \\
\hline Serratia marcescens SRM & Flower of Cucurbita pepo & $\begin{array}{l}\text { P-solublization, IAA, } \\
\text { Siderophore \& HCN } \\
\text { production }\end{array}$ & Selvakumar et al. (2008b) \\
\hline $\begin{array}{l}\text { Rhodococcus erythropolis } \\
\text { MtCC } 7905\end{array}$ & Magnesite Mines & $\begin{array}{l}\text { Chromium reduction, IAA } \\
\& \text { Siderophore production }\end{array}$ & Trivedi et al. (2007) \\
\hline Pantoea dispersa $1 \mathrm{~A}$ & NW Indian Himalaya & $\begin{array}{l}\text { P-solublization, IAA } \\
\text { production, HCN production }\end{array}$ & Selvakumar et al. (2008a) \\
\hline Pseudomonas sp. PGERs17 & Garlic root & $\begin{array}{l}\text { P- solublization, antagonistic } \\
\text { to Sclerotium rolfsii, } \\
\text { Fusarium oxysporum, } \\
\text { Rhizoctonia solani \& Pythium }\end{array}$ & Mishra et al. (2008) \\
\hline Exiguobacterium acetylicum $1 \mathrm{P}$ & Rhizosphere of apple tree & $\begin{array}{l}\text { P-solublization, IAA } \\
\text { production, HCN production }\end{array}$ & Selvakumar et al. (2010) \\
\hline $\begin{array}{l}\text { Acinetobacter rhizosphaerae } \\
\text { BIHB } 723\end{array}$ & $\begin{array}{l}\text { Rhizosphere of } \\
\text { Hippophae rhamnoides }\end{array}$ & $\begin{array}{l}\text { P-solublization, IAA, } \\
\text { ACC deaminase production }\end{array}$ & Gulati et al. (2009) \\
\hline Rahnella sp. BHIB783 & $\begin{array}{l}\text { Rhizosphere of } \\
\text { Hippophae rhamnoides }\end{array}$ & $\begin{array}{l}\text { P-solublization, Siderophore, } \\
\text { IAA, ACC deaminase } \\
\text { production }\end{array}$ & Vyas et al. (2010) \\
\hline Pseudomonas lurida M2RH3 & $\begin{array}{l}\text { Rhizosphere of } \\
\text { radish plants }\end{array}$ & P-solublization & Selvakumar et al. (2011) \\
\hline
\end{tabular}


crops was found to induce numerous positive responses in plants (Table 3.). Pseudomonas fluorescens and Pantoea agglomerans have been reported to effectively improve plant growth of winter wheat crops in loamy soils (Egamberdiyeva and Höflich, 2003). The genus Pseudomonas acts as a natural $r$-strategist among soil microbial communities and several species in this genus were found to possess plant growth promoting characteristics. Halotolerant strains Pseudomonas putida UW4 and GR12-2 were found to promote plant growth in canola at cold temperatures (Cheng et al., 2007; Sun et al., 1995). Pandey and co-workers (2006) reported that Pseudomonas putida (B0) from a sub-alpine site located in central Himalayas is capable of growing at $4{ }^{\circ} \mathrm{C}$. The isolate was reported to solubilize phosphate, antagonize the fungal pathogens Alternaria alternata and Fusarium oxysporum and induce growth of maize under green house conditions. Pseudomonas lurida (M2RH3), isolated from rhizosphere of radish plants (Raphanus sativus) growing in high altitude regions of Himalayas was found to solubilize phosphate even under longer incubation periods and promote growth of wheat (Selvakumar et al., 2011). Pseudomonas sp. (PGERs17) isolated from garlic root grown in sub alpine regions of North Western Himalayas was found to be antagonistic to phytopathogens Sclerotium rolfsii, Fusarium oxysporum, Rhizoctonia solani and Pythium. Moreover, the strain was found to assist growth of wheat plants (Mishra et al., 2008). Several strains of psychrotrophic pseudomonads improved growth of wheat and also alleviated cold stress by increasing protein, phenolics and anthocyanin synthesis in leaves. In addition, they decreased electrolyte leakage as well as water loss in plants (Mishra et al., 2011b).

Several cold-tolerant mutants have been developed, with plant growth promoting efficiency at low temperatures (Mishra and Goel, 1999; Katiyar and Goel, 2004; Trivedi and Sa, 2008; Xu et al., 1998). "Ice minus" mutants of Pseudomonas syringae have been reported to prevent ice nucleation in plant leaves at lower temperatures (Xu et al., 1998). NTG ( $N$ '-methyl- $N$ '-nitro- $N$-nitrosoguanidine) mutated Pseudomonas corrrugata has been reported to effectively solubilize rock phosphate under low temperature conditions and promotes growth of wheat plants (Trivedi and Sa, 2008). A similar report was made by Katiyar and Goel (2004) on a cold tolerant mutant, P. flouresens (ATCC13525) - developed to increase rhizosphere competitiveness. This strain showed enormous increase in siderophore production and exhibited plant growth promotion of mung bean (Vigna radiata).

An unclassified firmicute, Exiguobacterium acetylicum, isolated from the North Western Indian Himalayan region was reported to show growth and plant growth promotion over a wide range of temperature from $4{ }^{\circ} \mathrm{C}$ to $42^{\circ} \mathrm{C}$. The bacterium demonstrated multiple plant growth promoting traits including solublization of phosphates and production of IAA, siderophores as well as hydrogen cyanide (Selvakumar et al., 2010). Cold tolerant strains Pantoea dispersa (1A) and Serratia marcescens (MTCC 8708) were reported to sustain IAA production at low temperatures and promote plant growth in wheat and summer squash (Cucurbita pepo) (Selvakumar et al., 2008a, b). A psychrotrophic actinobacterium - Rhodococcus erythropolis was reported to transform higher concentrations of toxic hexavalent chromium $\left(\mathrm{Cr}^{6+}\right)$ to non toxic trivalent form $\left(\mathrm{Cr}^{3+}\right)$, in addition to aiding growth of pea plants (Trivedi et al., 2007). Gulati and co-workers (2009) reported on high IAA-producing Acinetobacter rhizosphaerae isolated from common sea-buckthorn (Hippophae rhamnoides) growing in cold deserts of Himalayas. The isolate was found to promote plant growth in a number of crops including maize, pea, chickpea and barley in vitro and pea under field conditions. A novel psychrotrophic enterobacteriaceae member (Rahnella sp.) augmented plant growth through a number of mechanisms, such as production of siderophores, phytohormones, organic acids, and enzymes such as phytase and ACC deaminase in maize, pea, chickpea and barley under in vitro conditions and pea in the field (Vyas et al., 2010). Kaushik et al. (2002) reported the plant growth promotion in wheat crops at sub-optimal temperatures by two strains of Azospirillum brasilense. Bacterial ACC deaminase activity may be helpful in reducing the levels of ethylene produced at low temperatures and promote growth of plants (Saleem et al., 2007). Barka et al. (2006) demonstrated enhanced cold resistance and ACC deaminase activity by Burkholderia phyto frmans in grapevine.

Under sub-normal temperature conditions, yield of leguminous plants were found to be affected due to the reduced Rhizobium competitiveness, and nodule formation and functioning (Mishra et al., 2011a). Moreover, legumes cultivated in the arctic regions are exposed to a short growing season, a long photoperiod, low precipitation and low soil nitrogen levels (Bordeleau and Prévost, 1994). This necessitates the selection of cold-adapted rhizobial strains for increasing productivity of legumes under cold 
Table 3. Psychrotolerant plant growth promoting bacterial association with crops and their induced responses in plants.

\begin{tabular}{|c|c|c|c|c|}
\hline Strain & Crop & Temperature & Plant responses & References \\
\hline $\begin{array}{l}\text { Pseudomonas putida } \\
\text { (B0) }\end{array}$ & Zea mays var. QPM-1 & $22 \pm 2^{\circ} \mathrm{C}$ & $\begin{array}{l}\text { Resistance to fungal pathogens } \\
\text { Phytophthora parasitica } \\
\text { and Fusarium } s p\end{array}$ & Pandey et al., (2006) \\
\hline Pantoea dispersa 1A & $\begin{array}{l}\text { Triticum sp. } \\
\text { (cv. VL.802) }\end{array}$ & $22 \pm 1{ }^{\circ} \mathrm{C}$ & $\begin{array}{l}\text { Increase in root and shoot lengths } \\
\text { by } 38.5 \text { and } 12 \% \text {; root and shoot } \\
\text { dry mass by } 15.3 \text { and } 6.4 \%\end{array}$ & $\begin{array}{l}\text { Selvakumar et al., } \\
\text { (2008a) }\end{array}$ \\
\hline $\begin{array}{l}\text { Acinetobacter } \\
\text { rhizosphaerae } \\
\text { BIHB } 723\end{array}$ & Zea mays var. Girija & $25 \pm 2^{\circ} \mathrm{C}$ & $\begin{array}{l}\text { Increase in root and shoot lengths } \\
\text { by } 28 \text { and } 35 \% \text {; plant dry mass by } 34 \%\end{array}$ & Gulati et al., (2009) \\
\hline $\begin{array}{l}\text { Acinetobacter } \\
\text { rhizosphaerae } \\
\text { BIHB } 723\end{array}$ & $\begin{array}{l}\text { Pisum sativum var. } \\
\text { Palam priya }\end{array}$ & $25 \pm 2^{\circ} \mathrm{C}$ & $\begin{array}{l}\text { Increase in root and shoot lengths by } \\
23 \text { and } 34 \% \text {; plant dry mass by } 32 \%\end{array}$ & Gulati et al., (2009) \\
\hline $\begin{array}{l}\text { Acinetobacter } \\
\text { rhizosphaerae } \\
\text { BIHB } 723\end{array}$ & $\begin{array}{l}\text { Cicer arietinum var. } \\
\text { HPG } 17\end{array}$ & $25 \pm 2^{\circ} \mathrm{C}$ & $\begin{array}{l}\text { Increase in root and shoot lengths by } \\
16 \text { and } 15 \% \text {; plant dry mass by } 30 \%\end{array}$ & Gulati et al., (2009) \\
\hline $\begin{array}{l}\text { Acinetobacter } \\
\text { rhizosphaerae } \\
\text { BIHB } 723\end{array}$ & $\begin{array}{l}\text { Hordeum vulgare var. } \\
\text { Dolma }\end{array}$ & $25 \pm 2^{\circ} \mathrm{C}$ & $\begin{array}{l}\text { Increase in root and shoot lengths by } \\
24 \text { and } 19 \% \text {; plant dry mass by } 27 \%\end{array}$ & Gulati et al., (2009) \\
\hline $\begin{array}{l}\text { Pseudomonas lurida } \\
\text { M2RH3 }\end{array}$ & $\begin{array}{l}\text { Triticum sp. } \\
\text { (cv. VL.804) }\end{array}$ & $18 \pm 2^{\circ} \mathrm{C}$ & $\begin{array}{l}\text { Root and shoot length increased by } \\
47.5 \text { and } 13.3 \% \text {; increase in } \mathrm{N}, \mathrm{P} \text {, } \\
\mathrm{K} \text { uptake by } 26.31,40 \text { and } 47.16 \% \\
\text { respectively }\end{array}$ & $\begin{array}{l}\text { Selvakumar et al., } \\
\text { (2011) }\end{array}$ \\
\hline $\begin{array}{l}\text { Exiguobacterium } \\
\text { acetylicum } 1 \mathrm{P}\end{array}$ & $\begin{array}{l}\text { Triticum sp cv. } \quad \mathrm{VL} \\
802\end{array}$ & $22 \pm 1{ }^{\circ} \mathrm{C}$ & $\begin{array}{l}\text { Root and shoot length increased by } \\
16.54 \text { and } 8.16 \% \text {; increase in } \mathrm{N}, \mathrm{P} \text {, } \\
\mathrm{K} \text { uptake by } 51.9,38.5 \text { and } 45.4 \% \\
\text { respectively }\end{array}$ & $\begin{array}{l}\text { Selvakumar et al., } \\
\text { (2010) }\end{array}$ \\
\hline Mycobacterium sp. 44 & $\begin{array}{l}\text { Triticum aestivum } \mathrm{cv} . \\
\text { Bussard }\end{array}$ & $16^{\circ} \mathrm{C}$ & $\begin{array}{l}\text { Root and shoot dry mass increase } \\
\text { by }>110 \text { and }>130 \%\end{array}$ & $\begin{array}{l}\text { Egamberdiyeva and } \\
\text { Höflich, (2003) }\end{array}$ \\
\hline $\begin{array}{l}\text { Pseudomonas sp. } \\
\text { NARs9 }\end{array}$ & $\begin{array}{l}\text { Triticum sp. cv. } \\
\text { VL } 829\end{array}$ & $18^{\circ} \mathrm{C}$ & $\begin{array}{l}\text { Germination rate enhanced by } \\
19.2 \% \text {; shoot and root lengths } \\
\text { increase by } 30 \text { and } 22.9 \%\end{array}$ & Mishra et al., (2009) \\
\hline $\begin{array}{l}\text { Rhodococcus } \\
\text { erythropolis } \\
\text { MtCC } 7905\end{array}$ & $\begin{array}{l}\text { Pisum sativum var } \\
\text { Arkel }\end{array}$ & $10-15^{\circ} \mathrm{C}$ & $\begin{array}{l}\text { Mitigation of } \mathrm{Cr}^{6+} \text { caused stress; } \\
\text { increase in plant height and plant } \\
\text { dry weight by } 37.9 \text { and } 43.5 \% \\
\text { under Chromium stress conditions }\end{array}$ & Trivedi et al., (2007) \\
\hline $\begin{array}{l}\text { Serratia marcescens } \\
\text { SRM }\end{array}$ & $\begin{array}{l}\text { Triticum sp. cv. } \\
\text { VL } 802\end{array}$ & $22 \pm 1{ }^{\circ} \mathrm{C}$ & $\begin{array}{l}\text { Increase in root and shoot length by } \\
20.9 \text { and } 21.59 \% \text {; root and shoot } \\
\text { dry mass by } 15.38 \text { and } 28.5 \% \text {; } \\
\text { increase in N, P, K uptake by } \\
17.3,18.6 \% \text { and } 26.7 \%\end{array}$ & $\begin{array}{l}\text { Selvakumar et al., } \\
\text { (2008b) }\end{array}$ \\
\hline $\begin{array}{l}\text { Burkholderia phytofi } \\
\text { rmans PsJN }\end{array}$ & $\begin{array}{l}\text { Vitis vinifera L. cv. } \\
\text { Chardonnay }\end{array}$ & $26^{\circ} \mathrm{C}$ & $\begin{array}{l}\text { Tolerance to chilling effects; } \\
\text { increase in total phenolics, } \\
\text { photosynthetic activity }\end{array}$ & Barka et al., (2006) \\
\hline
\end{tabular}

climatic conditions. Cold-adapted rhizobial strains were isolated from leguminous plants growing in arctic and subarctic soils of Canada and reported to improve nodulation in legume Onobrychis viciifolia, however, they failed to nodulate agronomically important legumes (Prevost et al., 1999). In a later study, Prevost et al. (2003) reported that nodulation and growth could be increased by Sinorhizobium meliloti in alfalfa under rigorous cold conditions.

\section{Conclusion}

Most of the cold tolerant mechanisms of adaptation are known to us at this stage. However, some mechanisms are yet to be completely understood and the present classification of adaptations may even be revised in near future based on further studies. The present report was aimed at bringing out the use of plant growth promoting cold-adapted bacteria 
in agriculture and in particular, in cereal and leguminous crops. Studies on use of such bacteria for other temperate crops have a huge scope in the field of agriculture. Furthermore, the process of nutrient cycling which is affected due to drop in temperature can be dealt by making use of potential cold-adapted bacteria, which can continue the process even under unfavorably low temperature conditions. Among cold-adapted bacteria, psychrophilic bacteria were found to be sensitive to increased temperatures, finding difficulty in taking up oxygen required for their metabolism at temperatures above their maximum requirement. Moreover, psychrophilic enzymes possess weak conformational stability, which requires freezing temperatures for growth and maintenance. These properties make psychrophiles vulnerable and weak to temperate conditions. However, as mentioned earlier, psychrotolerant bacteria are more pronounced than psychrophiles and their survival even at higher temperatures makes them good potential candidates for screening of plant growth promoting characteristics.

\section{Acknowledgment}

This study was carried out with the support of "Cooperative Research Program for Agricultural Science \& Technology Development (Project No.PJ007880)", Rural Development Administration, Republic of Korea.

\section{References}

Appleby, J.L., J.S. Parkinson, and R.B. Bourret. 1996. Signal transduction via the multi-step phosphorelay: not necessarily a road less travelled. Cell 86:845-848.

Araki, T. 1992. An analysis of the effect of changes in growth temperature on proteolysis in vivo in the psychrophilic bacterium Vibrio sp. strain ANT-300. J. Gen. Microbiol. 138: 2075-2082.

Barka, E.A., J. Nowak, and C. Clément. 2006. Enhancement of chilling resistance of inoculated grapevine plantlets with a plant growth-promoting rhizobacterium, Burkholderia phyto frmans strain PsJN. Appl. Environ. Microbiol. 72:7246-7252.

Beck, E.H., R. Heim, and J. Hansen. 2004. Plant resistance to cold stress: mechanisms and environmental signals triggering frost hardening and dehardening. J. Biosci. 29:449-459.

Bordeleau, L.M. and D. Prévost. 1994. Nodulation and nitrogen fixation in extreme environments. Plant Soil 161:115-125.

Boyer, J.S. 1982. Plant productivity and environment. Science 218:443-448.

Carpousis, A.J. 2002. The Escherichia coli RNA degradosome: structure, function and relationship to other ribonucleolytic multienyzme complexes. Biochem. Soc. Trans. 30:150-155.

Chattopadhyay, M.K. 2000. Cold adaptation of Antarctic microorganisms - possible involvement of viable but nonculturable state. Polar Biol. 23:223-224.

Chattopadhyay, M.K. 2006. Mechanism of bacterial adaptation to low temperature. J. Biosci. 31:157-165.

Chattopadhyay, M.K. 2002. The cryoprotective effects of glycine betaine on bacteria. Trends Microbiol. 10:311.

Chattopadhyay, M.K. and M.V. Jagannadham. 2001. Maintenance of membrane fluidity in Antarctic bacteria. Polar Biol. 24: 386-388.

Cheng, Z., E. Park, and B.R. Glick. 2007. 1-Aminocyclopropane1-carboxylate (ACC) deaminase from Pseudomonas putida UW4 facilitates the growth of canola in the presence of salt. Can. J. Microbiol. 53:912-918.

Chu, J., X. Yao, and Z. Zhang. 2010. Responses of wheat seedlings to exogenous selenium supply under cold stress. Biol. Trace Elem. Res. 136:355-363.

Coker, J.A., P.P. Sheridan, J. Loveland-Curtze, K.R. Gutshall, A.J. Auman, and J.E. Brenchley. 2003. Biochemical characterization of a $\beta$-galatosidase with a low optimum obtained from an Antarctic Arthrobacter isolate. J. Bacteriol. 185:5473-5482.

D'Amico, S., P. Claverie, T. Collins, D. Georlette, E. Gratia, A. Hoyoux, M.A. Meuwis, G. Feller, and C. Gerday. 2002. Molecular basis of cold adaptation. Phil. Trans. R. Soc. Lond. B. 357:917-925.

Duman, J.G. and T.M. Olsen. 1993. Thermal hysteresis protein activity in bacteria, fungi, and phylogenetically diverse plants. Cryobiology 30:322-328.

Egamberdiyeva, D. and G. Höflich. 2003. Influence of growthpromoting bacteria on the growth of wheat in different soils and temperatures. Soil Biol. Biochem. 35:973-978.

Ercolini, D., F. Russo, A. Nasi, P. Ferranti, and F. Villani. 2009. Mesophilic and psychrotrophic bacteria from meat and their spoilage potential in vitro and in beef. Appl. Environ. Microbiol. 75:1990-2001.

Feller, G. and C. Gerday. 2003. Psychrophilic enzymes: hot topic in cold adaptation. Nat. Rev. Microbiol.1:200-208.

Fowler, S. and M.F. Thomashow. 2002. Arabidopsis transcriptome profiling indicates that multiple regulatory pathways are activated during cold acclimation in addition to the $\mathrm{CBF}$ cold response pathway. Plant Cell 14:1675-1690.

Franks, F. 1985. Biophysics and biochemistry at low temperatures. Cambridge University Press, New York.

Gianese, G., P. Argos, and S. Pascarella. 2001. Structural adaptation of enzymes to low temperatures. Protein Eng. 14:141-148.

Gilbert, J.A., P.L. Davies, and J. Laybourn-Parry. 2005. A hyperactive $\mathrm{Ca}^{2+}$-dependent antifreeze protein in an Antarctic bacterium. FEMS Microbiol. Lett. 245:67-72.

Gilbert, J.A., P.J. Hill, C.E.R. Dodd, and J. Laybourn-Parry. 2004. Demonstration of antifreeze protein activity in Antarctic lake bacteria. Microbiol. 150:171-180.

Goldstein, J., N.S. Pollitt, and M. Inouye. 1990. Major coldshock protein of Escherichia coli. Proc. Natl. Acad. Sci. USA. 
87:283-287.

Gow, J.A. and F.H.J. Mills. 1984. Pragmatic criteria to distinguish psychrophiles and psychrotrophs in ecological systems. Appl. Environ. Microbiol. 47:213-215.

Graumann, P.L. and M.A. Marahiel. 1999. Cold shock response in Bacillus subtilis. J. Mol. Microbiol. Biotechnol. 1:203-209.

Gruszecki, W.I. and K. Strzałka. 2005. Carotenoids as modulators of lipid membrane physical properties. Biochim. Biophys. Acta. 1740:108-115.

Gulati, A., P. Vyas, P. Rahi, and R.C. Kasana. 2009. Plant growth-promoting and rhizosphere-competent Acinetobacter rhizosphaerae strain BIHB 723 from the cold deserts of the Himalayas. Curr. Microbiol. 58:71-377.

Guy, C.L. 1990. Cold acclimation and freezing stress tolerance: Role of protein metabolism. Annu. Rev. Plant Physiol. Plant Mol. Biol. 41:187-223.

Hébraud, M. and P. Potier. 1999. Cold shock response and low temperature adaptation in psychrotrophic bacteria. J. Mol. Microbiol. Biotechnol. 1:211-219.

Heipieper, H.J., F. Meinhardt, and A. Segura. 2003. The cistrans isomerase of unsaturated fatty acids in Pseudomonas and Vibrio: biochemistry, molecular biology, and physiological function of a unique stress adaptive mechanism. FEMS Microbiol. Lett. 229:1-7.

Horn, G., W. Hofweber, W. Kremer, and H.R. Kalbitzer. 2007. Structure and function of bacterial cold shock proteins. Cell. Mol. Life. Sci. 64:1457-1470.

Huston, A.L., B. Methe, and J.W. Deming. 2004. Purification, characterization and sequencing of an extracellular cold-active aminopeptidase produced by marine psychrophile Colwellia psychrerythraea strain 34H. Appl. Environ. Microbiol. 70: 3321-3328.

Jagannadham, M.V., M.K. Chattopadhayay, and S. Shivaji. 1996. The major carotenoid pigment of a psychrophilic Micrococcus roseus strain: fluorescence properties of the pigment and its binding to membranes. Biochem. Biophys. Res. Commun. 220: 724-728.

Jagannadham, M.V., M.K. Chattopadhayay, C. Subbalakshmi, M. Vairamani, K. Narayanan, C.M. Rao, and S. Shivaji. 2000. Carotenoids of an Antarctic psychrotolerant bacterium Sphingobacterium antarcticus and a mesophilic bacterium Sphingobacterium multivorum. Arch. Microbiol. 173:418-424.

Jagtap, P. and M.K. Ray. 1999. Studies on the cytoplasmic protein tyrosine kinase activity of the Antarctic psychrophilic bacterium Pseudomonas syringae. FEMS Microbiol. Lett. 173:379-388.

Johns, G.C. and G.N. Somero. 2004. Evolutionary convergence in adaptation of proteins to temperature: A4-lactate dehydrogenases of Pacific damselfishes (Chromis spp.). Mol. Biol. Evol. 21:314-320.

Jones, P.G., R. Krah, S.R. Tafuri, and A.P. Wolve. 1992. DNA gyrase, CS7.4, and the cold shock response in Escherichia coli. J. Bacteriol. 174:5798-5802.

Kaneda, T. 1991. Iso- and anteiso- fatty acids in bacteria: biosynthesis, function and taxonomic significance. Microbiol. Rev. 55:288-302.
Kasuga, M., Q. Liu, S. Miura, K. Yamaguchi-Shinozaki, and K. Shinozaki. 1999. Improving plant drought, salt, and freezing tolerance by gene transfer of a single stress-inducible transcription factor. Nat. Biotechnol. 17:287-291.

Katiyar, V. and R. Goel. 2004. Siderophore mediated plant growth promotion at low temperature by mutant of fluorescent pseudomonad. Plant Growth Regul. 42:239-244.

Kaushik, R., A.K. Saxena, and K.V.B.R. Tilak. 2002. Can Azospirillum strains capable of growing at a sub-optimal temperature perform better in field-grown-wheat rhizosphere. Biol. Fertil. Soils 35:92-95.

Kawahara, H. 2002. The structures and functions of ice crystalcontrolling proteins from bacteria. J. Biosci. Bioeng. 94: 492-496.

Kawahara, H., N. Koda, M. Oshio, and H. Obata. 2000. A cold acclimation protein with refolding activity on frozen denatured enzymes. Biosci. Biotechnol. Biochem. 64:2668-2674.

Kiran, M.D., S. Annapoorni, I. Suzuki, N. Murata, and S. Shivaji. 2005. Cis-trans isomerase gene in psychrophilic Pseudomonas syringae is constitutively expressed during growth and under conditions of temperature and solvent stress. Extremophiles 9:117-125.

Kiran, M.D., J.S.S. Prakash, S. Annapoorni, S. Dube, T. Kusano, H. Okuyama, N. Murata, and S. Shivaji. 2004. Psychrophilic Pseudomonas syringae required trans monounsaturated fatty acid for growth at higher temperature. Extremophiles 8:401-410.

Knight, C.A., J. Hallett, and A.L. Devries. 1988. Solute effects on ice recrystallization: an assessment technique. Cryobiology 25:55-60.

Kozloff, L.M., M.A. Schofield, and M. Lute. 1983. Ice nucleating activity of Pseudomonas syringae and Erwinia herbicola. J. Bacteriol. 153:222-231.

Lee, R.E., G.J. Warren, and L.V. Gusta. 1995. Biochemistry of bacterial ice nuclei. p. 63-83 In F. Ray and W.K. Paul (ed.) Biological ice nucleation and its application. APS Press, St Paul, Minnesota.

Lindow, S.E., D.C. Arnym, and C.D. Upper. 1978. Erwinia herbicola: a bacterial ice nucleus active in increasing frost injury to corn. Phytopathol. 68:523-527.

Liu, S., J.E. Graham, L. Bigelow, P.D. Morse II, and B.J. Wilkinson. 2002. Identification of Listeria monocytogens genes expressed in response to growth at low temperature. Appl. Environ. Microbiol. 68:1697-1705.

Maki, L.R., E.L. Gaylan, M. Chang-Chein, and D.R. Caldwell. 1974. Ice nucleation induced by Pseudomonas syringae. Appl. Microbiol. 28:456-459.

Margesin, R., G. Neuner, and K.B. Storey. 2007. Cold-loving microbes, plants, and animals-fundamental and applied aspects. Naturewisenschaften 94:77-99.

Marx, J.G., S.D. Carpenter, and J.W. Deming. 2009. Production of cryoprotectant extracellular polysaccharide substances (EPS) by the marine psychrophilic bacterium Colwellia psychrerythraea strain $34 \mathrm{H}$ under extreme conditions. Can. J. Microbiol. 55:63-72.

Methe, B.A., K.E. Nelson, J.W. Deming, E. Melamud, X. 
Zhang, J. Moult, R. Madupu, W.C. Nelson, R.J. Dodson, L.M. Brinkac, S.C. Daugherty, A.S. Durkin, R.T. DeBoy, J.F. Kolonay, S.A. Sullivan, L. Zhou, T.M. Davidsen, M. Wu, A.L. Huston, M. Lewis, B. Weaver, J.F. Weidman, H. Khouri, T.R. Utterback, T.V. Feldblyum, and C.M. Fraser. 2005. The psychrophilic lifestyle as revealed by the genome sequence of Colwellia psychrerythraea $34 \mathrm{H}$ through genomic and proteomic analyses. Proc. Natl. Acad. Sci. USA. 102: 10913-10918.

Mishra, M. and R. Goel. 1999. Development of a cold resistant mutant of plant growth promoting Pseudomonas fluorescens and its functional characterization. J. Biotechnol. 75:71-75.

Mishra, P.K., S. Mishra, G. Selvakumar, S.C. Bisht, J.K. Bisht, S. Kundu, and H.S. Gupta. 2008. Characterization of a psychrotolerant plant growth promoting Pseudomonas sp. Strain PGERs17 (MTCC 9000) isolated from north western Indian Himalayas. Ann. Microbiol. 58:561-568.

Mishra, P.K., S. Mishra, S.C. Bisht, G. Selvakumar, S. Kundu, J.K. Bisht, and H.S. Gupta. 2009. Isolation, molecular characterization and growth-promotion activities of a cold tolerant bacterium Pseudomonas sp, NARs9 (MTCC9002) from the Indian Himalayas. Biol. Res. 42:305-313.

Mishra, P.K., P. Joshi, S.C. Bisht, J.K. Bisht, and G. Selvakumar. 2011a. Cold-tolerant agriculturally important microorganisms. p. 273-296. In D.K. Mageswari (ed.) Plant growth and health promoting bacteria. Microbiology Monographs V.18. Springer-Verlag, Berlin.

Mishra, P.K., S.C. Bisht, P. Ruwari, G. Selvakumar, G.K. Joshi, J.K. Bisht, J.C. Bhatt, and H.S. Gupta. $2011 \mathrm{~b}$. Alleviation of cold stress in inoculated wheat (Triticum aestivum L.) seedlings with psychrotolerant Pseudomonas from NW Himalayas. Arch. Microbiol. 193:497-513.

Mittler, R. 2006. Abiotic stress, the field environment and stress combination. Trends Plant Sci.11:15-19.

Morita, R.Y. 1975. Psycrophilic bacteria. Bacteriol. Rev. 39: 144-167.

Moyer, C.L. and R.Y. Morita. 2007. Psychrophiles and psychrotrophs. John Wiley \& Sons, Ltd. DOI: 10.1002/ 9780470015902.a0000402.pub2.

Muryoi, N., M. Sato, S. Kaneko, H. Kawaahara, H. Obata, M.W.F. Yaish, M. Griffth, and B.R. Glick. 2004. Cloning and expression of afpA, a gene encoding an antifreeze protein from the Arctic plant growth promoting rhizobacterium Pseudomonas putida GR12-2. J. Bacteriol. 186:5661-5671.

Obata, H., N. Muryoi, H. Kawahara, K. Yamade, and J. Nishikawa. 1999. Identification of a novel ice-nucleating bacterium of Antarctic origin and its ice nucleation properties. Cryobiology 38:131-139.

Okuyama, H., N. Okajima, S. Sasaki, S. Higashi, and N. Murata. 1991. The cis/trans isomerization of the double bond of a fatty acid as a strategy for adaptation to changes in ambient temperature in the psychrophilic bacterium, Vibrio sp. strain ABE-1. Biochim. Biophys. Acta. 1084:13-20.

Pandey, A., P. Trivedi, B. Kumar, and L.M.S. Palni. 2006. Characterization of a phosphate solublizing and antagonistic strain of Pseudomonas putida (B0) isolated from a sub-alpine location in the Indian central Himalaya. Curr. Microbiol. 53:102-107

Piette, F., S. D’Amico, G. Mazzucchelli, A. Danchin, P. Leprince, and G. Feller. 2011. Life in the cold: a proteomic study of coldrepressed proteins in the Antarctic bacterium Pseudoalteromonas haloplanktis TAC125. Appl. Environ. Microbiol. 77:3881-3883.

Polissi, A., W. De Laurentis, S. Zangrossi, F. Briani, V. Loghi, G. Pesole, and G. Deho. 2003. Changes in Escherichia coli transcriptome during acclimatization at low temperature. Microbiol. Res. 154:573-580.

Prevost, D., P. Drouin, and H. Antoun. 1999. The potential use of cold adapted rhizobia to improve nitrogen fixation in legumes cultivated in temperate regions. p. 161-176. In R. Margesin and F. Schinner (ed.) Biotechnological application of cold-adapted organisms. Springer, Berlin.

Prevost, D., P. Drouin, S. Laberge, A. Bertrand, J. Cloutier, and G. Levesque. 2003. Cold-adapted rhizobia for nitrogen fixation in temperate regions. Can. J. Bot. 81:1153-1161.

Purusharth, R.I., F. Klein, S. Sulthana, S. Jager, M.V. Jagannadham, E.E. Hackenberg, M.K. Ray, and G. Klug. 2005. Exoribonuclease $\mathrm{R}$ interacts with endoribonuclease $\mathrm{E}$ and RNA helicase in the psychrotrophic bacterium Pseudomonas syringae Lz4W. J. Biol. Chem. 280:14572-14578.

Ray, M.K. 2006. Cold-stress response of low temperature adapted bacteria. p. 1-23. In A.S. Sreedhar and U.K. Srinivas (ed.) Stress response: A molecular biology approach. Research Signpost, India.

Ray, M.K., G. Seshu Kumar, and S. Shivaji. 1994a. Phosphorylation of membrane proteins in response to temperature in an Antarctic Pseudomonas syringae. Microbiol. 140:3217-3223.

Ray, M.K., T. Sitaramamma, S. Gandhi, and S. Shivaji. $1994 b$. Occurrence and expression of $\operatorname{csp} A$, a cold shock gene in Antarctic psychrotrophic bacteria. FEMS Microbiol. Lett. 116:55-60.

Ray, M.K., G.S. Kumar, K. Janiyani, K. Kannan, P. Jagtap, M.K. Basu, and S. Shivaji. 1998. Adaptation to low temperature and regulation of gene expression in Antarctic psychrotrophic bacteria. J. Biosci. 23:423-435.

Raymond, J.A. and A.L. DeVries. 1977. Adsorption inhibition as a mechanism of freezing resistance in polar fishes. Proc. Natl. Acad. Sci. USA. 74:2589-2593.

Roberts, M.E. and W.E. Inniss. 1992. The synthesis of cold shock proteins and cold acclimation proteins in the psychrophilic bacterium Aquaspirillum articum. Curr. Microbiol. 25:275-278.

Robertson, G.P. and A.S. Grandy. 2005. Soil system management in temperate regions. P. 27-39. In N.T. Uphoff (ed.) Biological approaches to sustainable soil systems. CRC Press, Boca Raton, Florida.

Russell, N.J. 1997. Psychrophilic bacteria-molecular adaptations of membrane lipids. Comp. Biochem. Psysiol. 118A:489-493.

Saleem, M., M. Arshad, S. Hussain, and A.S. Bhatti. 2007. Perspective of plant growth promoting rhizobacteria (PGPR) containing ACC deaminase in stress agriculture. J. Ind. Microbiol. Biotechnol. 34:635-648.

Sano, F., N. Asakawa, Y. Inouye, and M. Sakurai. 1999. A dual role for intracellular trehalose in the resistance of 
yeast cells to water stress. Cryobiology 39:80-87.

Sardesai, N. and C.R. Babu. 2001. Poly-ß-hydroxybutyrate metabolism is affected by changes in respiratory enzymatic activities due to cold stress in two psychrotrophic strains of Rhizobium. Curr. Microbiol. 42:53-58.

Selvakumar, G., S. Kundu, P. Joshi, S. Nazim, A.D. Gupta, and H.S. Gupta. 2010. Growth promotion of wheat seedlings by Exiguobacterium acetylicum 1P (MTCC 8707) a cold tolerant bacterial strain from Uttarakhand Himalayas. Indian J. Microbiol. 50:50-56.

Selvakumar, G., M. Mohan, S. Kundu, A.D. Gupta, S. Nazim, and H.S. Gupta. 2008b. Cold tolerance and plant growth promotion potential of Serratia marcescens strain SRM (MTCC 8708) isolated from flowers of summer squash (Cucurbita pepo). Lett. Appl. Microbiol. 46:171-175.

Selvakumar, G., S. Kundu, P. Joshi, S. Nazim, A.D. Gupta, P.K. Mishra, and H.S. Gupta. 2008a. Characterization of a cold-tolerant plant growth -promoting bacterium Pantoea dispersa 1A isolated from a sub-alpine soil in the north western Indian Himalayas. World J. Microbiol. Biotechnol. 24:955-960

Selvakumar, G., P. Joshi, P. Suyal, P.K. Mishra, G.K. Joshi, J.K. Bisht, J.C. Bhatt, and H.S. Gupta. 2011. Pseudomonas lurida M2RH3 (MTCC 9245), a psychrotolerant bacterium from the Uttarakhand Himalayas, solubilizes phosphate and promotes wheat seedling growth. World J. Microbiol. Biotechnol. 27:1129-1135.

Shivaji, S. and J.S.S. Prakash. 2010. How do bacteria sense and respond to low temperature? Arch. Microbiol. 192:85-95.

Shivaji, S., M.D. Kiran, and S. Chintalapati. 2007. Perception and transduction of low temperature in bacteria. p. 194207. In C. Gerday and V.N. Glansdor (ed.) Physiology and biochemistry of extremophiles. ASM Press, Washington.

Solanke, A.U. and A.K. Sharma. 2008. Signal transduction during cold stress in plants. Physiol. Mol. Biol. Plants 14: 69-79.

Sun, X., M. Griffith, J.J. Pasternak, and B.R. Glick. 1995. Low temperature growth, freezing survival, and production of antifreeze protein by the plant growth promoting rhizobacterium Pseudomonas putida GR12-2. Can. J. Microbiol. 41:776-784.

Trivedi, P. and T. Sa. 2008. Pseudomonas corrugata (NRRL B-30409) mutants increased phosphate solublization, organic acid production, and plant growth at lower temperatures. Curr. Microbiol.56:140-144.

Trivedi, P., A. Pandey, and T. Sa. 2007. Chromate reducing and plant growth promoting activities of psychrotrophic Rhodococcus erythropolis MtCC 7905. J. Basic Microb. 47:513-517.

Turner, M.A., F. Arellano, and L.M. Kozloff. 1991. Components of ice nucleation structures of bacteria. J. Bacteriol. 173: 6515-6527.

Vyas, P., R. Joshi, K.C. Sharma, P. Rahi, A. Gulati, and A. Gulati. 2010. Cold-adapted and rhizosphere-competent strain of Rahnella sp. with broad-spectrum plant growth-promotion potential. J. Microbiol. Biotechnol. 20:1724-1734.

Weber, M.H., W. Klein, L. Müller, U.M. Niess, and M.A. Marahiel. 2001. Role of the Bacillus subtilis fatty acid desaturase in membrane adaptation during cold shock. Mol. Microbiol. 39:1321-1329.

Xu, H., M. Griffth, C.L. Patten, and B.R. Glick. 1998. Isolation and characterization of an antifreeze protein with ice-nucleation activity from the plant growth promoting rhizobacterium Pseudomonas putida GR12-2. Can. J. Microbiol. 44:64-73.

Yamashita, Y., N. Nakamura, K. Omiya, J. Nisikawa,, H. Kawahara, and H. Obata. 2002. Identification of an antifreeze lipoprotein from Moraxella sp. of Antarctic origin. Biosci. Biotechnol. Biochem. 66:239-247.

Zacharuassen, K.E. and E. Kristiansen. 2000. Ice nucleation and anti-nucleation in nature. Cryobiology 41:257-279.

Zhang, W. and L. Shi. 2005. Distribution and evolution of multiple-step phosphorelay in prokaryotes: lateral domain recruitment involved in the formation of hybrid-type histidine kinases. Microbiol. 151:2159-2173. 